\title{
Present and Future of Endoscopy in Spinal Surgery
}

\author{
Salim Senturk ${ }^{1}$, Ulkun Unlu Unsal ${ }^{1 *}$, Berkay Paker ${ }^{2}$, Onur Yaman ${ }^{1}$ and Ali Fahir Ozer ${ }^{1}$ \\ ${ }^{1}$ Department of Neurosurgery, KOC University Hospital, Turkey \\ ${ }^{2}$ School of Medicine, KOC University, Turkey
}

Submission: August 29, 2017; Published: October 25, 2017

*Corresponding author: Ulkun Unlu Unsal, Department of Neurosurgery, KOC University Hospital, Turkey, Email: ulkununlu@hotmail.com

\section{Mini Review}

Endoscopic spine surgery markedly improved in the last ten years and still is continuing to improve. Due to less soft tissue damage and shorter time to return to normal life for patients, interest to this type of surgery is increasing. Definition of safe access zone for transforaminal approach by Kambin \& Gelman [1] and in following years arthroscopic micro discectomy technique defined by Kambin [2] was effective in the improvement of endoscopic spinal surgery [1,2]. Today endoscope is used in cervical, thoracic and lumbar spinal surgery.

\section{Endoscopic approaches in cervical spinal surgery}

In cervical region, endoscopic approaches can be anterior and posterior. In endoscopic anterior cervical discectomy; protruded or extruded part of the targeted disc is reached and excised under fluoroscopy control. This technique is preferred since the risk of neighbor segment disease is less and it protects segmental mobility [3]. There are difficulties in patients with marked osteophytes blocking foramen access [4]. Posterior cervical lamino-foraminotomy is a common surgical technique however, due to muscle tissue damage and postop kyphosis it causes widespread neck and shoulder pain. Conversely with full posterior endoscopic approach in short surgical durations enough decompression can be achieved [5]. Patient is placed in prone position and working cannula is placed on the foramen to be decompressed. Foramen is opened with diamond burr.

\section{Endoscopic approaches in thoracic spinal surgery}

In thoracic spine video assisted thoracoscopic surgery (VATS) and transforaminalendoscopic surgery techniques are used.

VATS: It is based on the principle of performing discectomy with several surgical instruments and a camera inserted through ribs but due to entry risk to thorax and high learning curve it presents serious challenges [6]. In 1999 Jho [7] defined endoscopic transpedicular thoracic discectomy technique but transforaminal endoscopic discectomy with differing ratios of facet excision is more commonly used $[7,8]$. In this technique patient is placed in prone position. Jamshidi needle is placed to the foramen from $5 \mathrm{~cm}$ lateral of midline under the control of fluoroscopy. Without passing the midpedicular line working cannula is placed to the foramen. Foramen is widened with diamond burr to reach disc. Afterwards disc is removed with endoscope. When these procedures are performed, it is controlled with fluoroscopy [3].

\section{Endoscopic approaches in lumbar spinal surgery}

Although in lumbar disc surgery primary method is microdiscectomy in last ten years tendency to endoscopic discectomy is markedly increased. According to the disc pathology there are basically two different approaches; transforaminal and interlaminar. In transfroaminal endoscopic discectomy patient is placed in prone position. A needle is placed to the foramen from $10-12 \mathrm{~cm}$ lateral to the midline under fluoroscopy control. Working cannula is placed to foramen and disc level. With this technique protruded and foraminal discs at the level can be easily reached. In order to reach extruded discs widening of the defect in the capsule might be needed. Superiorly or inferiorly migrated discs can be reached with foraminoplasty with diamond burr. Reccurrence rates in transforaminal endoscopic discectomy reported $0 \%$ to $12 \%$ [9].

Interlaminar endoscopic discectomy is especially preferred in L5-S1 discs but it can be applied to superior disc levels. In this technique, patient is placed in prone position and an $8 \mathrm{~mm}$ incision is made to the disc level and side. Working cannula is placed to the interlaminar window between muscles under fluoroscopy control (with anteroposterior and lateral images). Ligamentum Flavum is seen with endoscope and then resected with micro punch. Depending on the situation micro rongeur can be used. After ligament is passed working cannula can be placed and dura nad root can be dissected. Herniated disc is seen and extracted. In order to reach superior disc levels, with diamond burr, laminotomy and facetectomy is performed. In superior disc levels discs which are compressing axilla or root can be excised however this method shouldn't be preferred on wide based discs [10]. 


\section{Open Access Journal of Neurology \& Neurosurgery}

In lumbar spinal stenosis cases one sided or bilateral spinal canal decompression can be achieved with interlaminar approach. Working cannula is placed lateral to the compressed level with inter laminar approach. With diamond burr lamina is removed from inferior part of the superior lamina until the ligamentum flavum is thinned. Superior part of the inferior lamina is also removed. Bipolar radiofrequency electrocoagulator is used for hemostasis. Afterwards with the help of a punch ligamentum favum is removed. With this procedure ipsilateral and contralateral decompression can be achieved [11]. Iatrogenic instability rates are lower when compared to the other surgical techniques.

In endoscopic spinal surgery; operation duration, blood loss, patients' hospital stay, postop painkiller usage, infection rates and CSF leaks are less than the other surgical techniques [11]. Besides that patients' return to normal life and workplace is quicker so socioeconomic loss rate are lower.

\section{Endoscopic future of endoscope in spinal surgery}

In recent years usage of endoscope in spinal surgery is increased. In future it is expected to be more widespread. It is planned to perform surgeries with better imaging systems and with 3D images [3]. At the same time, in order to increase the sensitivity of the hand movements of surgeons and reduce the complication rates it is expected that robotic surgery will be used in spinal surgeries.

\section{References}

1. Kambin P, Gellman H (1983) Percutaneous lateral discectomy of the lumbar spine a preliminary report. Clin Orthop Relat Res 174: 127132
2. Kambin P (1991) Arthroscopic microdiskectomy. Mt Sinai J Med 58(2): 159-164.

3. Middleton SD, Wagner R, Gibson JNA (2017) Multi-level spine endoscopy. A review of available evidence and case report. EFORT Open Rev 2017 2(7): 317-323.

4. Yang B, Xie J, Yin B, Wang L, Fang S, et al. (2014) Treatment of cervical disc herniation through percutaneous minimally invasive techniques. Eur Spine J 23(2): 382-388

5. Clark JG, Abdullah KG, Steinmetz MP, Benzel EC, Mroz TE (2011) Minimally invasive versus open cervical foraminotomy: a systematic review. Global Spine J 1(1): 9-14

6. Jeon SH, Lee SH (2013) Thoracoscopic discectomy. In: Lewandrowski $\mathrm{KU}$, Lee SH, Iprenburg M, (Eds.), Endoscopic spinal surgery. London: JP Medical Publishers, pp. 75-78.

7. Jho HD (1999) Endoscopic transpedicular thoracic discectomy. J Neurosurg 91: 151-156

8. Choi KY, Eun SS, Lee SH, Lee HY (2010) Percutaneous endoscopic thoracic discectomy; transforaminal approach. Minim Invasive Neurosurg 53: 25-28.

9. Gadjradj PS, van Tulder MW, Dirven CM, Peul WC, Harhangi BS (2016) Clinical outcomes after percutaneous transforaminal endoscopic discectomy for lumbar disc herniation: a prospective case series. Neurosurg Focus 40(2): E3.

10. Jun-ichiro Nakamura, Kiyoshi Yoshihara (2017) Initial Clinical Outcomes of Percutaneous Full Endoscopic Lumbar Discectomy Using anInterlaminar Approach at the L4-L5. Pain Physician 20(4): E507-E512.

11. Hyeun Sung Kim, Byapak Paudel, Ji Soo Jang, Seong Hoon Oh, Sol Lee, et al. (2017) Percutaneous Full Endoscopic Bilateral Lumbar Decompression of Spinal Stenosis Through Uniportal-Contralateral Approach: Techniques and Preliminary Results. World Neurosurg 103: 201-209.

\section{Your next submission with Juniper Publishers will reach you the below assets}

- Quality Editorial service

- Swift Peer Review

- Reprints availability

- E-prints Service

- Manuscript Podcast for convenient understanding

- Global attainment for your research

- Manuscript accessibility in different formats

( Pdf, E-pub, Full Text, Audio)

- Unceasing customer service

Track the below URL for one-step submission https://juniperpublishers.com/online-submission.php 